\title{
nature
}

\section{Courage, vision and the Department of Energy}

Federico Peña Is heading for one of the hottest seats In the United States government. He will need farsighted resolve to pursue his department's controversial goals.

T he secretary of energy is the only one of Washington's elite band of science administrators to enjoy a full place in the President's cabinet, and also the only one to be replaced so far by President Bill Clinton as he embarks upon his second four-year term. But the job seldom allows much opportunity for its occupant to bask in the reflected glory of the department's scientific achievements, which are considerable. Instead, the management of the Department of Energy \$6-billion research portfolio and its other activities tends to involve every energy secretary in protracted political infighting by virtue of the wide portfolio of controversial issues on the department's turf.

The tenure of Federico Peña, who is likely to succeed Hazel O'Leary in the position after his successful confirmation hearings before the Senate last week (see page 472), will doubtless reverberate to a long series of public clashes with the many interests whose representatives feel entitled to tell the energy department what to do. Add to that the recent danger that the Congress would try to abolish the department altogether, and it is no wonder that anyone arriving in this position will do so with low expectations.

Yet Peña enters this particular hornets' nest with some advantages. One is that the abolitionists are in retreat: the Republicans, who still control the Congress, appear to have lost their revolutionary appetite for dismemberment. Another advantage is that the main components of the department are in the hands of seasoned assistant secretaries well able to defend their programmes in the Congress without much help from the secretary's office. That said, if Peña is confirmed, he can be sure that the thorniest issues will land squarely in his lap.

These include reform of the large network of laboratories, including the three associated with nuclear weapons, that the department operates. Two years ago this week, a panel chaired by the industrialist Robert Galvin called for dramatic action to improve their efficiency. The laboratories and their friends in Congress have successfully opposed wholesale reform, but its rapid implementa- tion would ultimately be in their own best interests.

The stockpile stewardship programme, which will replace nuclear testing with a \$4-billion-a-year research and development programme based on new supercomputers and experimental facilities, has strong bipartisan support and seems unlikely to come unstuck on Peña's watch. An even larger programme to clean up the defunct nuclear weapons production complex will continue to run into various local difficulties at sites across the country. But some necessary cuts in the programme have been made, and improvements in its management should soon start to bear fruit.

The problem that could occupy the largest slice of Peña's attention throughout his tenure, however, is the disposal of spent fuel from nuclear power stations. The electricity utilities have paid billions in levies towards the costs of a permanent store. Next year, the department will complete its assessment of Yucca Mountain, Neva$\mathrm{da}$, as a suitable site. Peña's task is to convince people that he will stand up to both the utilities and the environmentalists and handle Yucca on the basis of what is right for the United States.

O'Leary once said that the energy department should really be called the department of science and technology. But, in fact, the department's central mission today is to manage the tangled legacy of outdated priorities and nuclear waste. O'Leary was sometimes chastised for her lack of attention to detail, but her own track record on this central mission has been impressive. She tried to open up the department to a deeply suspicious public, and she brought round recalcitrant laboratory directors to a world without nuclear tests.

Federico Peña comes to the department with no experience of the relevant technical issues, but with a reputation as a hard worker and something of a visionary. He will be judged not on his grasp of unfamiliar detail but on the courage he shows in confronting special interests, and the vision he can formulate for a department that has yet to come fully to terms with the end of the Cold War.

\section{Avoid financial 'correctness'}

\section{Insistence that authors declare business interests in papers is beside the point.}

t t comes as no surprise to find (Nature 385, 376; 30 January 1997) that about one-third of a group of life scientists working in the biotechnologically rich state of Massachusetts had financial interests in work that they published in academic journals in 1992. Nor, given the absence of policies of most journals at the time, is it surprising that those interests were seldom declared in their papers. More recently, some journals have insisted on declarations of interest, either to editors only or in published papers.

This journal has never required that authors declare such affiliations, because the reasons proposed by others are less than compelling. It would be reasonable to assume, nowadays, that virtually every good paper with a conceivable biotechnological relevance emerging from the west and east coasts of the United States, as well as many European laboratories, has at least one author with a financial interest - but what of it? The measurements and conclusions are in principle unaffected, as is the requirement that uncertainties be made clear. Would the impact on readers of a declaration of interest differ from that of a statement that the success of the next grant application will be that much greater as a result of publication? And who is to police disobedience? Such appeals for openness are selective - other pieces of information would be just as (ir)relevant to a paper's content.

The work published (Science and Engineering Ethics 2, 395;1996) makes no claim that the undeclared interests led to any fraud, deception or bias in presentation, and until there is evidence that there are serious risks of such malpractice, this journal will persist in its stubborn belief that research as we publish it is indeed research, not business. 